\title{
Investigation of Coke Formation on H-ZSM-5 Catalyst During Aromatization of C5 Paraffin and Olefin Using Optical and Fluorescence Microscopy
}

\author{
Young-Min Chung* \\ Department of Nano \& Chemical Engineering, Kunsan National University \\ 558 Daehak-ro, Miryong-dong, Kunsan-si, Jeonbuk 573-701, Korea
}

(Received for review July 3, 2013; Accepted July 11, 2013)

\begin{abstract}
요 약
광학 및 형광 현미경을 이용한 실시간 촉매 모니터링 기술을 활용하여 C5 파라핀과 올레핀의 방향족화 반응 중 H-ZSM-5 촉 매 표면에서 발생하는 코크 형성 과정을 시간별, 촉매 위치별로 관찰하였다. 실시간 자외-가시광 분광현미경(in-situ UV-vis microspectroscopy) 실험을 통해 반응 중 촉매 표면에서 발생하는 코킹 현상에 대한 정보를 실시간으로 얻을 수 있었으며, 그 결과, 결정의 위치와 반응물의 종류에 따라 코크 형성이 크게 달라짐을 확인하였다. 실시간 공초점형 형광현미경(in-situ confocal fluorescence microscopy) 연구에서는, $488 \mathrm{~nm}$ 레이저에 의해 형광을 나타내는 화학종들은 높은 분포로 결정의 중앙 부분에 존재하며, $561 \mathrm{~nm}$ 레이저에 의해 형광을 발현하는 화학종들은 촉매 결정의 외곽으로 이동하는 것을 관찰하였다. 이 러한 결과는, 코크 전구체의 크기에 따라 형광 발현 현상이 다르며, 따라서, 촉매의 위치에 따라 다른 종류의 코크 전구체가 존재한다는 것을 시사한다.
\end{abstract}

주제어 : 코킹, 비활성화, 방향족화반응, 현미경, 제올라이트

\begin{abstract}
Space- and time-resolved in-situ optical and fluorescence microspectroscopy techniques have been applied to investigate the coke formation during aromatization of C5 paraffin and olefin over H-ZSM-5 crystal. In-situ UV/vis absorption measurement offers space- and time-resolved information for the coke formation. Different coking trends have been observed with respect to the location of a crystal as well as the reactant types. From in-situ confocal fluorescence microspectroscopy study, it is revealed that the concentration of certain species photo-excited at $488 \mathrm{~nm}$ becomes high at the central region, whereas the compounds emitting fluorescence by $561 \mathrm{~nm}$ laser move towards the boundary region of the crystal. The different fluorescence patterns obtained varying excitation lasers suggest the existence of distinct fluorescence emitting species having different degree of coke growth.
\end{abstract}

Keywords : Coking, Deactivation, Aromatization, Microscopy, Zeolite

\section{Introduction}

In hydrocarbon processing, formation of carbonaceous materials on working catalysts is usually inevitable and the undesired coke deposition generally provokes loss of activity and change in selectivity. Therefore, a great number of studies have been carried out to understand the nature of coke and thus to find efficient methods preventing or alleviating the unfavorable catalyst deactivation[1,2]. However, the nature of the carbonaceous species is still a matter of debate and the subject of many investigations. Although various characterization techniques, e.g., infrared (IR), ultraviolet and visible spectroscopy (UV-Vis), electron spin resonance (ESR), nuclear magnetic resonance (NMR), and X-ray excited photoelectron spectroscopy (XPS) have been applied to elucidate the nature of coke[3], the investigation of

\footnotetext{
* To whom correspondence should be addressed.

E-mail: ymchung@kunsan.ac.kr
}

doi:10.7464/ksct.2013.19.3.327 coke formation under reaction conditions is still limited. In this regard, it is natural that in-situ characterization technique has drawn attention with hope that the versatile method adopting a broad range of analytical techniques offers new insight into the investigation of active site and the related reaction mechanism in a working catalyst[4,5].

Aromatization of paraffin or olefin is one of the important methods to convert excess low-value light hydrocarbons into aromatics which can be used as chemical feedstocks as well as highoctane gasoline blending components[6-8]. However, the severe catalyst deactivation of the attractive reaction should be improved to meet industrial requirement. To achieve the elusive goal, it is clear that more detailed information for the coke formation on working catalyst is necessary. However, the complex reaction mechanism as well as fast coke deposition has been an obstacle for in-depth characterization.

In this context, it is aimed here to present the application of in-situ optical and fluorescence microspectroscopy techniques 
for the investigation of the coke formation during aromatization of C5 paraffin and olefin over H-ZSM-5 crystal. The space- and time-resolved characterizations show that coke deposition rate and patterning of the coke formation within zeolite crystals are strongly dependent upon the reactant types and the location of crystal.

\section{Experimental}

\subsection{Materials and experiments}

The large H-ZSM-5 crystallites were provided by ExxonMobil (Machelen, Belgium). The detailed information can be found in previous publications[9-11]. The H-ZSM-5 crystal $(\mathrm{Si} / \mathrm{Al}=7)$ has typical dimensions of $100 \mu \mathrm{m} \times 20 \mu \mathrm{m} \times 20 \mu \mathrm{m}$. Representative C5 chemicals such as 2-methyl-butane and 2-methyl-2butene are supplied from Aldrich and used without further purification. The experiments were performed in an appropriate in-situ cell (Linkam FTIR 600) equipped with a temperature controller (Linkam TMS 93). The calcined crystals were heated to $773 \mathrm{~K}$ at the rate of $10 \mathrm{Kmin}^{-1}$ and kept at this temperature for $1 \mathrm{~h}$ under inert atmosphere with $\mathrm{N}_{2}$. After the in-situ cell temperature was stabilized, the nitrogen flow was diverted through a bubbler containing 2-methyl-butane or 2-methyl-2-butene solution thereby acting as carrier gas. During an experiment, the bubbler was chilled with ice to control the evaporation rate of the volatile feedstock.

\subsection{Optical microspectroscopy setup}

An Olympus BX41 upright microscope equipped with a $50 \times$ 0.5 NA-high working distance objective was used. A $75 \mathrm{~W}$ tungsten lamp provided the illumination. The in-situ setup was equipped with a 50/50 double-viewpoint tube, that accommodates a CCD video camera (ColorView IIIu, Soft Imaging System $\mathrm{GmbH}$ ) and an optical fiber mount. A $200 \mu \mathrm{m}$-core fiber connected the microscope to a CCD UV/vis spectrometer (AvaSpec-2048TEC, Avantes).

\subsection{Confocal fluorescence microspectroscopy setup}

In-situ fluorescence studies were performed on a Nikon Eclipse LV150 upright microscope equipped with Nikon D-Eclipse C1 head connected to the laser light sources (488 and $561 \mathrm{~nm}$ ). The emission was detected with two photomultiplier tubes in the 510-550 and 575-635 nm range. The confocal fluorescence measurement was carried out at the middle horizon plane parallel to the upper plane in the crystal center. During an experiment, the confocal images were collected alternatively changing 488 and $561 \mathrm{~nm}$ lasers in every 8 seconds.

\section{Results and Discussion}

\subsection{In-situ optical microspectroscopy}

The optical microphotographs presented in Figure 1 show the color change of H-ZSM-5 crystals during the aromatization of representative C5 paraffin (2-methyl-butene) and olefin (2-methyl2-butene) as a function of time at $773 \mathrm{~K}$. Upon exposure to reactant vapor, the translucent H-ZSM-5 crystals gradually become yellow-brown as the formation of carbonaceous deposition increases.

It is observed that not only the color change rate but also the coloration intensity varies depending on the kind of reactants. With paraffin, the color change rate is slow and the coloration intensity is weak. In the case of olefin, on the other hand, the coloration rate is so fast that the color of H-ZSM-5 crystals turns dark brown or black indicating faster coke deposition.

Time-resolved in-situ optical absorption measurements taken from a $2 \mu \mathrm{m}$ spot in the central region of the H-ZSM-5 crystals during the aromatization are shown in Figure 2. The optical absorption measurements clearly reflect the different color variation of H-ZSM-5 crystals originated from different coking rates. In the case of paraffin, the absorption intensity is very low and little change is observed.

The aromatization reaction begins with the chain growth of small olefins and then the resulting aliphatic olefins transform to light alkyl aromatics by cyclization as described in Figure 3. Considering the reaction pathways of aromatization and coke formation[3,12,13], the slow coke deposition confirmed by the low absorption intensity indicates slow dehydration or cracking of paraffin to smaller olefin within H-ZSM-5 crystals. (a)

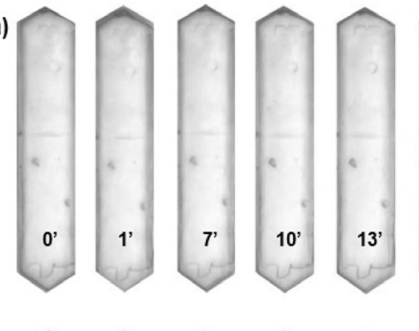

(b)



Figure 1. Optical microphotographs of H-ZSM-5 crystals taken during aromatization at $773 \mathrm{~K}$; (a) reaction with 2-methylbutane, (b) reaction with 2-methyl-2-butene. The corresponding time is indicated in minutes. 
(a)

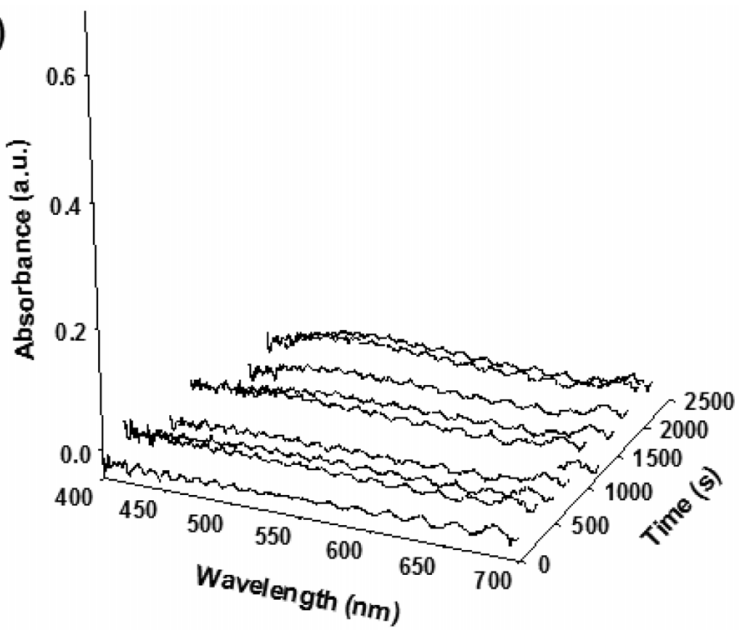

(b)

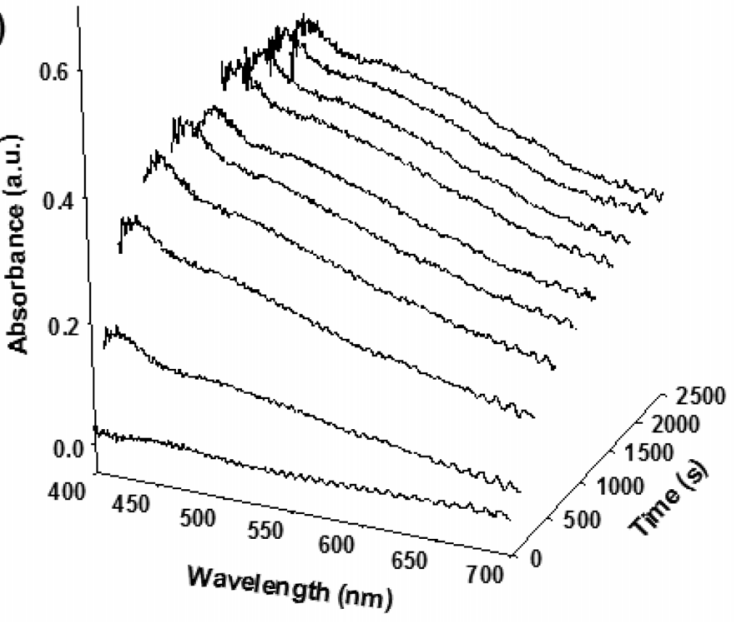

Figure 2. Optical absorption spectra of H-ZSM-5 crystals taken during aromatization at $773 \mathrm{~K}$; (a) reaction with 2-methylbutane, (b) reaction with 2-methyl-2-butene. The spectra were taken from a spot in the crystal center.
Although one can assume that the transformation of paraffin to olefin is fast and olefinic or polyolefinic coke precursor (coke type I) may be formed in the pore, it is not plausible because these polyenylic cations are easily transformed to coke type II (typically small aromatic carbocations and bulky polyaromatics) at high temperature[3]. In addition, it is difficult to confirm the existence of the light cokes due to a limitation in the detection range of optical microscopy $(400 \sim 700 \mathrm{~nm})$. The optical absorption of the light coke deposition is usually found below $390 \mathrm{~nm}$.

On the other hand, two broad bands around 410 and $550 \mathrm{~nm}$ are observed during an aromatization of olefin. The absorption band around $410 \mathrm{~nm}$ is assigned to the $\pi-\pi^{*}$ transition of lowcondensed aromatics, e.g., diphenyl and polyalkylaromatics, while the band around $550 \mathrm{~nm}$ is responsible for the optical absorption of extended conjugated aromatic species such as polyphenyl and polyaromatic cations[3,11]. The broad background absorption across the optical region suggests the relevant growth of condensed aromatic species to larger delocalized polyaromatics with graphitic nature[14]. Therefore, the appearance of two strong absorption bands around 410 and $550 \mathrm{~nm}$ clearly supports the faster formation of carbonaceous deposits in the case of olefin aromatization. It should be noted that few studies have been reported for the reaction due to the fast deactivation $[11,15]$.

Figure 4 shows the optical absorption spectra of H-ZSM-5 crystals taken from a spot in the crystal edge during an aromatization of olefin. The dominant absorption around $500 \sim 580 \mathrm{~nm}$ wavelengths as well as stronger background absorption across the whole visible region clearly shows that the coke deposition is more severe in the edge region comprised of straight pores compared to the central region with zigzag pores[9]. The fast coke deposition results in fast catalyst deactivation. In particular,

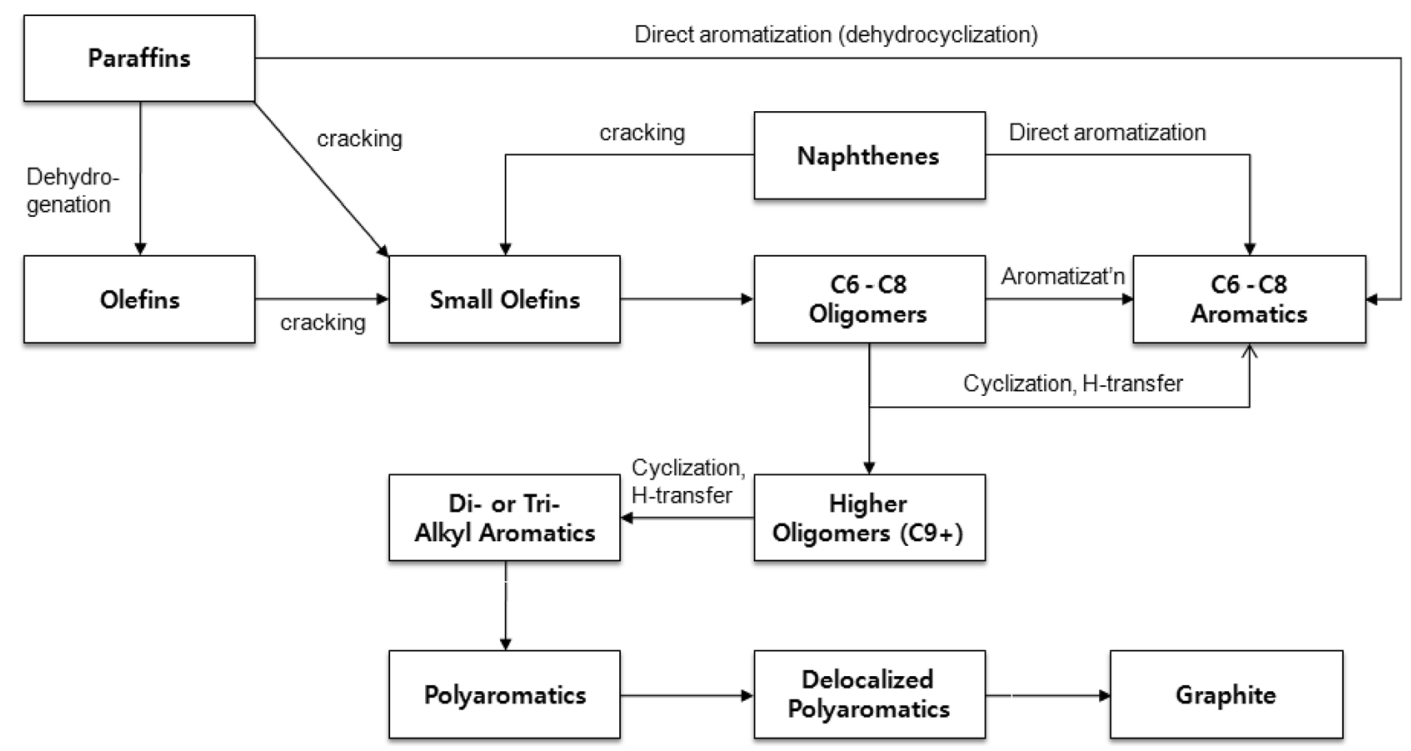

Figure 3. Reaction pathways for aromatization and coke formation over H-ZSM-5. 
it is noteworthy that the intensity of absorption band around $410 \mathrm{~nm}$ changes after ceasing the olefin supply. With continuing olefin supply, the intensity of the band around $410 \mathrm{~nm}$ is maintained regardless of the gradual growth of the band around 550 $\mathrm{nm}$. This indicates that the coke growth cycle is maintained by continuous feed supply. In other words, the coke precursors having strong absorption around $410 \mathrm{~nm}$ is continuously generated and some part of the species may be transformed to bigger ones identified by the absorption band around $550 \mathrm{~nm}$. After ceasing the olefin supply, it is observed that the band around $550 \mathrm{~nm}$ grows up at the expense of the decrease in the absorption around $410 \mathrm{~nm}$ (Figure 4(b)).

The red shift supports the transformation of low-condensed aromatics to heavy-condensed ones inside the zeolite crystal. The in-situ UV/vis microspectroscopy study clearly demonstrates the different coke formation trend depending on the reactant as well as the location of crystal.

(a)


Figure 4. Optical absorption spectra of H-ZSM-5 crystals taken during aromatization with 2-methyl-2-butene at $773 \mathrm{~K}$; (a) during reaction $(0 \sim 2400 \mathrm{~s})$, (b) $\mathrm{N}_{2}$ purge after ceasing feed-in $(2400 \sim 3600 \mathrm{~s})$. The spectra were taken from a spot in the crystal edge.

\subsection{In-situ confocal fluorescence microspectroscopy}

In-situ confocal fluorescence microscopy study has also been carried out to elucidate the spatial distribution of coke precursors during an aromatization. Figure 5 shows the confocal images of the H-ZSM-5 crystals taken during the reaction. The confocal images were collected alternatively changing 488 and $561 \mathrm{~nm}$ lasers in every 8 seconds with fluorescence detection windows at 510-550 and 575-635 nm, respectively. At the beginning of the reaction, intense fluorescence at the central region is immediately observed and there is little difference between the distributions of the respective fluorescent species with various excitation lasers. The weak fluorescence at the crystal edge region may be due to the fast accumulation of graphitic coke species implying that the coking process is too fast to observe at the edge region. As shown in Figure 5, however, it is revealed that the patterns obtained at varying excitation wavelengths change with time on

(a)

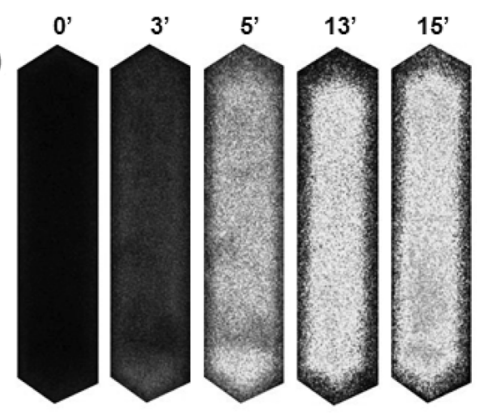

(b)

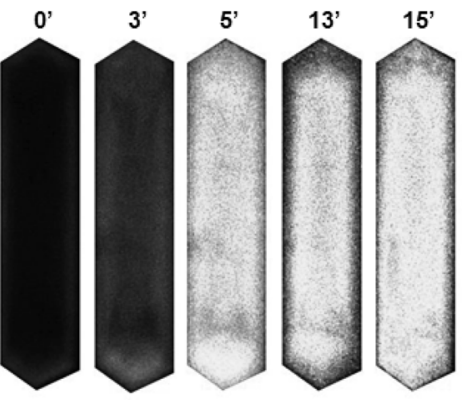

(c)

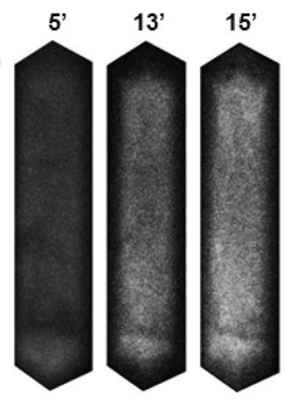

Figure 5. Confocal fluorescence microphotographs of H-ZSM-5 crystal measured during aromatization at $773 \mathrm{~K}$ depicted with time-on-stream. (a) excitation at $488 \mathrm{~nm}$, detection at $510-550 \mathrm{~nm},($ b) excitation at $561 \mathrm{~nm}$, detection at 565 $635 \mathrm{~nm}$, false colors represent fluorescence intensity. (c) true color image in the $510-550 \mathrm{~nm}$ and $565-635 \mathrm{~nm}$ range. The corresponding time is indicated in minutes. 
stream. The concentration of the fluorescent species excited by $488 \mathrm{~nm}$ laser becomes high at the central region, whereas the compound emitting fluorescence by $561 \mathrm{~nm}$ laser moves towards the boundary region of the crystal. The different fluorescence phenomena indicate that they correspond to distinct species, most likely, differing in their molecular dimensions. In the present case, it can be due to the different degree of coke growth. The identification of these different coke precursors is difficult at this stage. However, it can be assumed that the former species excited at $488 \mathrm{~nm}$ may be lighter coke precursors compared to those excited at $561 \mathrm{~nm}$ considering that the fluorescent species photo-excited at $488 \mathrm{~nm}$ readily penetrate towards the inner core of the crystal compared to the compounds excited at $561 \mathrm{~nm}[9]$. The red shift in the excitation wavelength indicates a large molecular size.

In line with the previous study[9], the fluorescence profiles during the aromatization can be explained. At the early stage of reaction, light coke precursors are produced and widely distributed within H-ZSM-5 crystal. As time goes on, a portion of the light coke precursors are gradually transformed to more condensed ones. The bigger species either migrate from the internal channels to the channel mouths at the external surfaces or reorganize to fit the channel dimensions because the restricted space in ZSM-5 channels inhibits the formation of bulky polyaromatic compounds[14,16].

The explanation is supported by the fluorescence photograph image which clearly shows that the concentration of lighter coke precursors is high at the central region, whereas larger amount of the bigger carbonaceous species is distributed at the edge region (Figure 5(c)). Once the external surfaces are researched, the carbonaceous species can grow without any steric limitation, giving rise to insoluble "coke" which is responsible for catalyst deactivation by causing pore mouth blocking. These results clearly demonstrate that the in-situ confocal fluorescence microspectroscopy offers significant advantages to investigate the coke transportation and deposition within zeolite pores in a spaceresolved manner.

\section{Conclusion}

Coke formation during aromatization of paraffin and olefin over H-ZSM-5 zeolite crystal has been investigated in a spaceand time-resolved manner. With optical microphotograph image analysis, it is found that coloration intensities and color change rates of crystals varied depending on the reactant types. In the case of olefin aromatization, faster color change of crystal suggests faster coke deposition compared to that of paraffin. In-situ $\mathrm{UV} /$ vis absorption measurements show different coking trend with respect not only to the reactant types but also to the location of a crystal. In particular, the transformation of low-con- densed aromatics to heavy-condensed ones inside the zeolite crystal is also observed after ceasing olefin supply. In-situ confocal fluorescence microspectroscopy is also applied to elucidate the coke migration and deposition within zeolite pores in a spaceresolved manner. It is revealed that the fluorescence patterns are dependent upon the excitation lasers. The different fluorescence tendencies indicate that they correspond to the different degree of coke growth. The in-situ fluorescence microspectroscopy combined with UV/vis analogue gives valuable insights into the coke deposition on zeolite crystals during aromatization of C5 paraffin and olefin.

\section{Acknowledgement}

This paper was supported by research funds of Kunsan National University.

\section{Reference}

1. Wolf, E. E., and Alfani, F., "Catalysts Deactivation by Coking," Catal. Rev. Sci. Eng., 24(3), 329-371 (1982).

2. Bhatia, S., Beltramini, J., and Do, D. D., "Deactivation of Zeolite Catalysts," Catal. Rev. Sci. Eng., 31(4), 431-480 (1989).

3. Bauer, F., and Karge, H. G., "Characterization of Coke on Zeolites,” Mol. Sieves, 5, 249-364 (2007).

4. Weckhuysen, B. M., (Ed), In-situ Spectroscopy of Catalysts, American Scientific Publishers, Stevenson Ranch, 2004.

5. Weckhuysen, B. M., "Chemical Imaging of Spatial Heterogeneities in Catalytic Solids at Different Length and Time Scales," Angew. Chem. Int. Ed., 48, 4910-4943 (2009).

6. Nishi, K., Komai, S.-I., Inagaki, K., Satsuma, A., and Hattori, T., "Structure and Catalytic Properties of Ga-MFI in Propane Aromatization," Appl. Catal. A: Gen., 223(1-2), 187-193 (2002).

7. Changlin, Lubango, L. M., and Scurrell, M. S., "Light Alkanes Aromatization to BTX over Zn-ZSM-5 Catalysts: Enhancements in BTX Selectivity by Means of a Second Transition Metal Ion," Appl. Catal. A: Gen., 235(1-2), 265-272 (2002).

8. Choudhary, V. R., Banerjee, S., and Panjala, D., "Product Distribution in the Aromatization of Dilute Ethene over HGaAlMFI Zeolite: Effect of Space Velocity," Micropor. Mesopor. Mater., 51(3), 203-210 (2002).

9. Stavitski, E., Kox, M. H. F., and Weckhuysen, B. M., "Revealing Shape Selectivity and Catalytic Activity Trends within the Pores of H-ZSM-5 Crystals by Time- and Space-resolved Optical and Fluorescence Microspectroscopy," Chem. Eur. J., 13, 7057-7065 (2007).

10. Mores, D., Stavitski, E., Kox, M. H. F., Kornatowski, J., Olsbye, U., and Weckhuysen, B. M., "Space- and Time-Resolved Insitu Spectroscopy on the Coke Formation in Molecular Sieves: Methanol-to-Olefin Conversion over H-ZSM-5 and H-SAPO34," Chem. Eur. J., 14, 11320-11327 (2008). 
11. Chung, Y.-M., Mores, D., and Weckhuysen, B. M., "Spatial and Temporal Mapping of Coke Formation during Paraffin and Olefin Aromatization in Individual H-ZSM-5 Crystals," Appl. Catal. A: Gen., 404, 12-20 (2011).

12. Viswanadham, N., Pradhan, A. R., Ray, N., Vishnoi, S. C., Shanker, U., and Rao, T. S. R. P., "Reaction Pathways for the Aromatization of Paraffins in the Presence of H-ZSM-5 and Zn/H-ZSM-5," Appl. Catal. A: Gen., 137(2), 225-233 (1996).

13. Bartholomew, C. H., "Mechanisms of Catalyst Deactivation," Appl. Catal. A: Gen., 212(1-2) 17-60 (2001).
14. Palumbo, L., Bonino, F., Beato, P., Bjørgen, M., Zecchina, A., and Bordiga, S., "Conversion of Methanol to Hydrocarbons: Spectroscopic Characterization of Carbonaceous Species Formed over H-ZSM-5," J. Phys. Chem. C, 112, 9710-9716 (2008).

15. Nagamori, Y., and Kawase, M., "Converting Light Hydrocarbons Containing Olefins to Aromatics (Alpha Process), Micropor. Mesopor. Mater., 21(4-6), 439-445 (1998).

16. Olsbye, U., Bjorgen, M., Svelle, S., Lillerud, K. P., and Kolboe, S., "Mechanistic Insight into the Methanol-to-hydrocarbons Reaction," Catal. Today, 106(1-4), 108-111 (2005). 